\title{
Pendekatan Struktur Aktivitas dan Penambatan Molekul Senyawa 2-iminoethyl 2-(2-(1- hydroxypentan-2-yl) phenyl)acetate Hasil Isolasi Fungi Endofit Genus Fusarium sp pada Enzim $\beta$-ketoasil-ACP KasA Sintase dan Enzim Asam Mikolat Siklopropana Sintase
}

\author{
Rollando Rollando \\ Program Studi Farmasi, Fakultas Sains dan Teknologi, Universitas Ma Chung, Malang, Indonesia
}

\section{INFO ARTIKEL}

Sejarah artikel:

Penerimaan naskah:

19 Desember 2017

Penerimaan naskah revisi:

3 Mei 2018

Disetujui untuk

dipublikasikan: 26 Juni

2018

\section{Kata kunci :}

Asam mikolat

siklopropana sintase, $\beta$ -

ketoasil-ACP KasA

sintase, 2-iminoethyl 2-

(2-(1-hydroxypentan-2-yl)

phenyl)acetate.

\section{A B S T R A K}

Fungi endofit dapat memproduksi senyawa yang memiliki aktivitas biologi, diantaranya senyawa flavonoid, alkaloid, fenolik, dan terpenoid. Fungi endofit genus Fusarium sp yang diisolasi dari daun tanaman meniran menghasilkan senyawa 2-iminoethyl 2-(2-(1-hydroxypentan-2-yl) phenyl)acetate yang mempunyai aktivitas dapat menghambat pertumbuhan bakteri Mycobacterium tuberculosis dengan nilai EC50 sebesar 18,98 $\mu \mathrm{M}$. Penelitian ini bertujuan untuk mengetahui mekanisme aksi senyawa 2-iminoethyl 2-(2-(1-hydroxypentan-2-yl) phenyl)acetate pada enzim asam mikolat siklopropana sintase dan $\beta$-ketoasilACP KasA sintase. Enzim asam mikolat siklopropana sintase dan enzim $\beta$-ketoasil-ACP KasA sintase memiliki andil yang besar dalam pembentukan asam mikolat yang bila terhambat dapat menyebabkan kematian pada bakteri Mycobacterium tuberculosis. Pendekatan dilakukan dengan metode penambatan molekul (ArgusLab 4.0.1) dengan didahului optimasi dan validasi metode. Reseptor yang digunakan adalah 2WGE dan 3HEM yang didapat dari Protein Data Bank. Hasil analisis menunjukan senyawa 2iminoethyl 2-(2-(1-hydroxypentan-2-yl) phenyl)acetate mampu berikatan dengan lebih baik terhadap enzim asam mikolat siklopropana sintase dan enzim $\beta$-ketoasil-ACP KasA sintase dibandingkan dengan ligan positif dan ligan asli. Dari analisis tersebut disimpulkan bahwa senyawa 2-iminoethyl 2-(2-(1hydroxypentan-2-yl) phenyl)acetate mampu bertindak sebagai inhibitor enzim asam mikolat siklopropana sintase dan enzim $\beta$-ketoasil-ACP KasA sintase pada bakteri Mycobacterium tuberculosis secara in-silico.

\section{Structure-Activity and Molecular Docking Approach of 2-iminoethyl 2-(2-(1- hydroxypentan-2-yl) phenyl)acetate (an Isolation Product of Fusarium sp) on $\beta$-ketoacyl- ACP KasA and Cyclopropane Mycolic Acid Synthase Enzyme}

\section{Keywords:}

Cyclopropanic acid synthase, $\beta$-ketoacyl-ACP KasA synthase, 2iminoethyl 2-(2-(1hydroxypentan-2yl)phenyl)acetate.
A B S TR A C T

Endophytic fungi can produce compounds that have biological activities, including flavonoid, alkaloid, phenolic, and terpenoid compounds. Endophytic fungi of the genus Fusarium sp isolated from the leaves of meniran plant produce 2-iminoethyl 2-(2-(1-hydroxypentan-2-yl)phenyl)acetate that can inhibit the growth of Mycobacterium tuberculosis with EC50 value of $18,98 \mu \mathrm{M}$. The aim of this research is to predict the mechanism of 2-iminoethyl 2-(2-(1-hydroxypentan-2-yl)phenyl)acetate on the cyclopropanic acid synthase and $\beta$-ketoacyl-ACP KasA synthase enzymes using in-silico approach. Cyclopropanic acid synthase enzyme and $\beta$-ketoacyl gauze-ACP synthase enzyme has a significant role in the formation of mikolat acid which when inhibited can cause death in the bacterium Mycobacterium tuberculosis. Approach was done using molecular docking method (ArgusLab 4.0.1) with optimization and validation method. The receptors used were 2WGE and 3HEM obtained from Protein Data Bank. The results showed that 2-iminoethyl 2-(1-hydroxypentan-2-yl)phenyl) acetate compound was able to bind better to the Cyclopropanic acid synthase and $\beta$-ketoacyl-ACP KasA synthase compared to the positive ligand and native ligand. We conclude that the 2-iminoethyl 2-(1-hydroxypentan-2-yl) phenyl) can potentially act as an inhibitor for both cyclopropanic acid synthase and $\beta$-ketoacyl-ACP KasA synthase enzymes in Mycobacterium tuberculosis as indicated by in-silico prediction. 


\section{Pendahuluan}

Tuberkulosis merupakan penyakit infeksi penyebab kematian terbesar kedua di dunia setelah Human Immuno Deficiency Virus. Pada tahun 2011, terdapat sekitar 313.601 kasus baru tuberkulosis di Indonesia ${ }^{1}$. Terapi lini pertama tuberkulosis dilakukan dengan kombinasi obat antituberkulosis INH dan rifampisin. Penggunaan obat antituberkulosis secara kombinasi dalam waktu yang lama cenderung menyebabkan ketidakpatuhan pasien minum obat, yang selanjutnya memicu resistensi bakteri Mycobacterium tuberculosis terhadap obat antituberkulosis ${ }^{2}$. Data tahun 2016 menunjukan sebanyak $5 \%$ dari 10,5 juta kejadian tuberkulosis disebabkan adanya resistensi obat yang diberikan pada terapi lini pertama ${ }^{3}$.

Oleh karena itu, penemuan dan pengembangan antituberkulosis perlu terus dilakukan, salah satunya dari bahan alam. Resistensi bakteri terhadap antibiotik menyebabkan proses pengobatan infeksi menjadi sulit, misalnya berkembang resistensi bakteri Pseudomonas aeruginosa terhadap antibiotik amikacin, tobramycin, dan gentamicin yang disebut MARPA (multiple antibioticresistant Pseudomonas aeruginosa $)^{4}$, bakteri Staphylococcus aureus yang resisten terhadap methicillin atau yang disebut MRSA (Methicillin resistant Staphylococcus aureus) $)^{5}$. Berdasarkan data tersebut diperlukan usaha untuk memperoleh senyawa antibakteri baru seperti melalui sintesis kimia, isolasi dari tanaman, atau penemuan mikroba penghasil antibiotik.

Fungi endofit merupakan organisme dengan ukuran mikroskopis yang hidup di dalam jaringan tanaman daun, akar, dan batang6. Fungi endofit menghasilkan senyawa flavonoid, alkaloid, fenolik, dan terpenoid yang memiliki aktivitas farmakologi ${ }^{7}$, seperti senyawa antibakteri, antikanker, antimalaria, antivirus, antifungi, dan sebagainya ${ }^{8}$. Salah satu contoh spesies fungi endofit adalah Diaporthe phaseolorum yang menghasilkan senyawa antibakteri, yaitu asam 3-hidroksipropanoat ${ }^{9}$.

Penelitian ini merupakan penelitian lanjutan dari penelitian yang dilakukan oleh Rollando, et $a l^{10}$. Dari penelitian tersebut, fungi endofit genus Fusarium sp. menghasilkan senyawa2-iminoethyl 2-(2-(1-hydroxypentan2-yl) phenyl)acetate (Gambar 1) yang aktif sebagai antibakteri dan antikanker. Senyawa 2-iminoethyl 2-(2-(1hydroxypentan-2-yl) phenyl)acetate dapat menghambat pertumbuhan bakteri Mycobacterium tuberculosis dengan nilai $\mathrm{EC}_{50}$ sebesar $18,98 \mu \mathrm{M}$, tergolong bakterisidal, dan mempunyai prospek yang baik untuk dikembangkan sebagai antituberkolosis ${ }^{10}$. Secara garis besar, mekanisme aksi senyawa tersebut belum diselidiki secara pasti dan diperlukan pendekatan ilmiah untuk mengetahui mekanisme aksi. Oleh sebab itu, dalam penelitian ini dilakukan pendekatan struktur aktivitas dan pendekatan penambatan molekul (molecular docking) guna mencari mekanisme aksi dengan akurasi dan presisi pendekatan yang tinggi yang didahului proses optimasi dan validasi metode komputasi ${ }^{10}$.

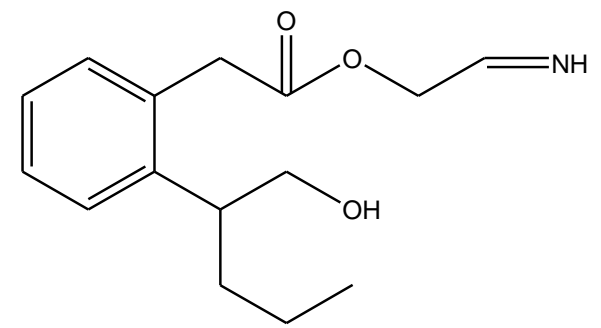

Gambar 1.Struktur Senyawa 2-iminoethyl 2-(2-(1-hydroxypentan-2yl)phenyl)acetate

\section{Metode}

Pembuatan Struktur 3 Dimensi Senyawa2-iminoethyl 2-(2(1-hydroxypentan-2-yl) phenyl)acetate

Struktur 3 dimensi senyawa 2-iminoethyl 2-(2-(1hydroxypentan-2-yl) phenyl)acetate yang digunakan dibentuk menggunakan program Chem $3 D$ Ultra. Bentukan ini berdasarkan data 2 dimensi yang akan diskrining. Setelah dibentuk secara manual, struktur tersebut disimpan sebagai suatu template . $p d b$. Kemudian struktur tersebut dibuka lewat program VegaZZ lalu ditambahkan hidrogen. Mikromolekul kemudian diperbaiki muatannya dengan menambahkan muatan parsial Gasteiger Charges dan diberi forcefield Autodock. Minimisasi dan pencarian konformasi dilakukan sebanyak 3000 langkah.

\section{Pengunduhan Makromolekul Target}

Makromolekul diunduh dari situs penyedia PDB makromolekul http://www.pdb.org. Kemudian dimasukkan identitas struktur tiga dimensi yang diinginkan untuk diunduh. Data makromolekul disimpan sebagai bentuk . $p d b$. Untuk penelitian ini, data makromolekul yang diunduh adalah 2WGE (Crystal structure of KasA of Mycobacterium tuberculosis with bound TLM) dan 3HEM (Mycolic Acid Cyclopropane Synthase CmaA2 in Complex with Dioctylamine).

\section{Validasi Metode Penambatan Molekul}

Program ArgusLab divalidasi untuk menunjukkan bahwa metode tetap yang digunakan sesuai dengan tujuan penggunaannya dan selalu memberikan hasil yang dapat dipercaya. Native Ligand di-copy, di-paste dan ligand yang dihasilkan disebut ligand copy. Ligand copy di-docking-kan pada ligand binding site receptor dengan metode ArgusDoc. Dilakukan perbandingan nilai ikatan antara ligan pembanding-ligand binding site receptor dengan ikatan ligandcopy-ligand binding site receptor. Analisa data perbandingan nilai dinyatakan dengan RMSD (Rate Mean Square Deviation). Metode docking dikatakan baik jika nilai RMSD-nya lebih kecil atau sama dengan 2,5 $(\leq 2,5)$. Jika nilai RMSD yang diperoleh lebih besar dari 2,5 (> 2,5), metode yang digunakan tidak dapat dipercaya. 


\section{Pemisahan Rantai Makromolekul untuk Target Penambatan}

Struktur tiga dimensi dari protein 2WGE dan 3HEM memiliki rantai-rantai hidrofobik. Rantai pada makromolekul tersebut dipisahkan menggunakan aplikasi UCSF Chimera. Hasil pemisahan tersebut akan digunakan dalam pengujian superposisi. Makromolekul yang memiliki banyak rantai umumnya tidak dapat disuperposisi secara langsung oleh sebab itu rantai tersebut dipisahkan terlebih dahulu. Makromolekul juga dipisahkan dari pelarut (air) dan ligan atau residu nonstandar menggunakan perangkat lunak yang sama.

\section{Superposisi Rantai}

Superposisi rantai dilakukan menggunakan PyMol seperti yang dilakukan oleh DeLano (2009). Rantai makromolekul yang telah dipisahkan sebelumnya digunakan sebagai bahan superposisi. Superposisi dilakukan dengan keluaran (output) file disimpan dengan menggunakan format . $p d b$. Rantai dalam satu makromolekul disuperposisi dengan rantai lain dalam makromolekul tersebut. Apabila superposisi antar rantai tersebut menghasilkan struktur yang mirip satu sama lain maka dipilih salah satunya saja sebagai target penambatan.

\section{Optimasi Molekul untuk Persiapan Penambatan}

Makromolekul yang sudah disuperposisi kemudian disiapkan untuk penambatan. Makromolekul dioptimasi dengan menggunakan aplikasi VegaZZ. Struktur tiga dimensi dari makromolekul tersebut ditambahkan kembali atom hidrogen. Makromolekul kemudian diperbaiki muatannya dengan menambahkan muatan parsial Gasteiger Charges dan diberi forcefield Autodock.

\section{Penambatan Molekul}

Penambatan molekul dilakukan menggunakan program Arguslab 4.01. Struktur makromolekul dan ligand yang akan ditambatkan dan telah dioptimasi secara terpisah disimpan dalam satu folder yang sama. Hasil penambatan disimpan dalam format $p d b$. dengan makromolekul.

\section{Analisa Data dan Evaluasi Penilaian (Scoring) Hasil Penambatan.}

Hasil penambatan divisualisasi menggunakan PyMOL. Parameter hasil penambatan dianalisis terhadap parameter penambatan yang telah ditentukan sebelumnya. Energi ikatan reseptor-ligand diperoleh melalui program Arguslab, melalui program Chimera dapat diamati residu asam amino yang terdekat dengan ligand $(<5 \AA$ ) $)$, dan jarak dan jenis ikatan reseptor-ligand dapat diamati melalui program PyMOL.

\section{Hasil}

\section{Pendekatan Struktur Aktivitas}

Mekanisme aktivitas antimikroba dari senyawa 2iminoethyl 2-(2-(1-hydroxypentan-2-yl) phenyl)acetate dapat dilakukan melalui pendekatan struktur-aktivitas dengan mencari senyawa yang secara struktur mempunyai gugus fungsi yang mirip dengan alkaloid imina. Senyawa 2iminoethyl 2-(2-(1-hydroxypentan-2-yl) phenyl)acetate memiliki kemiripan struktur dengan senyawa thiacetazone (Gambar 2), kedua senyawa memiliki gugus benzena yang terintegrasi dengan gugus samping karbonil dan imina. Thiacetazone merupakan obat yang digunakan sebagai antimikobakteri untuk penyakit tuberkolosis. Thiacetazone mempunyai sifat bakteriostatik bahkan pada dosis yang sangat tinggi, sehingga sering digunakan sebagai obat kombinasi bersamaan dengan isoniazid pada pengobatan tuberkolosis level pertama. Thiacetazone digunakan sebagai obat pilihan pertama pada penyakit tuberkolosis yang sudah resisten terhadap obat pilihan utama seperti rifamisin dan isoniazid ${ }^{11}$.<smiles>CC(=O)Nc1ccc(/C=N/NC(N)=S)cc1</smiles>

Gambar 2. Struktur Thiacetazone

Thiacetazone yang merupakan antimikobakteri yang bekerja dengan menghambat jalur biosintesis asam mikolat. Asam mikolat adalah asam lemak rantai panjang yang mempunyai peranan yang penting sebagai penyusun dinding sel mikobakteri. Mikobakteri patogen membawa jenis asam mikolat yang mempunyai cincin siklopropana. Ikatan rangkap di posisi tertentu pada prekusor asam mikolat, dibentuk dan dikatalisis oleh enzim asam mikolat siklopropana sintase (CMASs).Asam mikolat siklopropana merupakan faktor kunci dalam permeabilitas sel, imunomodulasi host, dan persistensi sel mikobakteri ${ }^{12}$.

Penelitian Alahari et al.,(2007) melaporkan bahwa senyawa thiacetazone memiliki target enzim asam siklopropana mikolat sintase. Uji pada bakteri strain Mycobacterium bovis BCG dan Mycobacterium marinum menunjukan bahwa terjadi penurunan produksi asam mikolat setelah diberi perlakuan thiacetazone. Analisis kombinasi metode kromatografi lapis tipis, spektrometri massa dan NMR menunjukan pada bahwa terjadi penurunan proses siklopropanasi pada kedua subtipe alpha dan asam mikolat teroksigenasi pada asam mikolat terpurifikasi.

Penelitian mengenai jalur penghambatan senyawa thiacetazone juga telah diteliti oleh Grzegorzewicz et al, ${ }^{13}$. Peneliti menguraikan proses biosintesis asam mikolat dan target aksi senyawa thiacetazone. Rantai $\mathrm{C}_{48}$ dan $\mathrm{C}_{54}$ meromikolat dibiosintesis oleh FAS-II melalui penambahan beberapa unit malonat ke prekusor $\mathrm{C}_{16}-\mathrm{C}_{26}$ yang dihasilkan oleh FAS-I. Substrat awal FAS-II dan keto-asil-ACP dihasilkan dari proses kondensasi oleh protein $M$. Tuberkulosis FabH yang merupakan produk asil-CoA dari FAS-I dengan malonil-ACP. Setelah proses reduksi oleh $\beta$ keto-asil-ACP MabA reduktase, penghilangan gugus $\mathrm{H}_{2} \mathrm{O}$ (hidrasi) oleh (3R)-hidroksasil HadAB dan HadBC 
dehidratase, dan reduksi oleh enoil-CoA InhA reduktase, baik $\beta$-ketoasil-ACP KasA dan KasB sintase akan mengkatalisis proses kondensasi dari penambahan produk dari unit malonil-ACP, dengan demikian akan memulai proses pemanjangan rantai. Produk FAS-II mungkin mengalami proses elongasi dan modifikasi rantai asam fungsional meromikolat yang dikatalisis oleh AdoMetdependen metiltransferase. Thiacetazone mempunyai peran dalam menghambat proses dehidrasi, dengan cara menghambat aktivitas enzim (3R)-hidroksasil HadAB dan HadBC dehidratase sehingga trans-enoil-ACP tidak terbentuk yang mengakibatkan prekusor $\mathrm{C}_{48}-\mathrm{C}_{62}-\mathrm{AMP}$ (meromikolat teraktivasi) tidak terbentuk dan pembentukan asam mikolat tidak terjadi (Gambar 3).

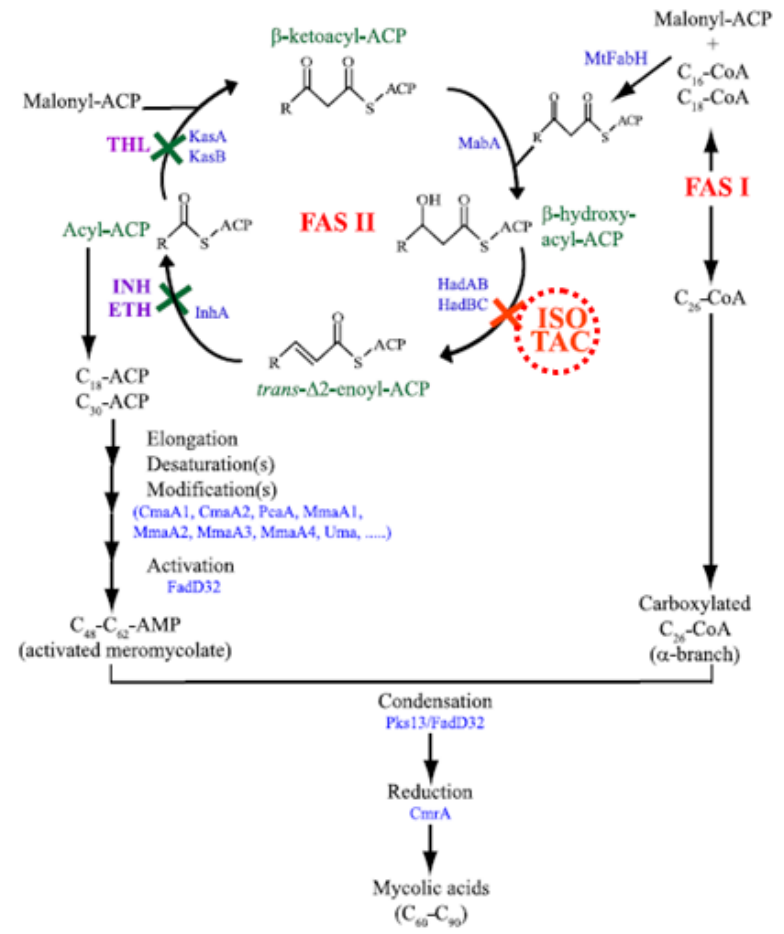

Gambar 3. Jalur Penghambatan Asam Mikolat oleh Thiacetazone ${ }^{12}$

\section{Pendekatan Penambatan Molekul}

Pendekatan aktivitas senyawa2-iminoethyl 2-(2-(1hydroxypentan-2-yl) phenyl)acetate dilakukan dengan metode penambatan molekul (molecular docking) untuk mengetahui proses pendekatan aktivitas molekular terhadap enzim target pada bakteri tuberkolosis. Analisis pendekatan struktur aktivitas melalui kemiripan struktur pada senyawa thiacetazone dan pendekatan jalur pembentukan asam mikolat menghasilkan beberapa target enzim yang menjadi tempat aksi senyawa thiacetazone yaitu (3R)-hidroksasil HadAB dan HadBC dehidratase ${ }^{14}$ dan asam siklopropan mikolat sintase ${ }^{15}$. Situs resmi makromolekul yaitu http://www.pdb.org hanya menyediakan bentuk kristal dari asam siklopropana mikolat sintase yang telah dikompleks bersama dengan ligan dengan kode protein $3 \mathrm{HEM}^{16}$. Selain itu, dengan tujuan untuk mengeksplorasi aktivitas senyawa 2-iminoethyl 2-(2-(1-hydroxypentan-2-yl) phenyl)acetate dengan lebih luas terhadap pembentukan asam mikolat, digunakan juga protein target yaitu enzim $\beta$-ketoasil-ACP KasA sintase tuberkolosis (kode protein: $2 \mathrm{WGE})^{12}$. Enzim $\beta$-ketoasil-ACP KasA sintase tuberkolosis memiliki andil yang besar dalam pembentukan asam mikolat, bila aktivitas enzim $\beta$-ketoasil-ACP KasA sintase terhambat maka pembentukan asam mikolat juga akan terhambat.

Enzim $\beta$-ketoasil-ACP KasA sintase dan asam mikolat siklopropana sintase telah dikristalisasi bersama dengan ligan utama yang telah mengalami proses pemetaan posisi interaksi dengan sisi aktif enzim. Enzim $\beta$-ketoasilACP KasA sintase memiliki ligan utama yaitu senyawa tiolaktomisin yang merupakan inhibitor enzim $\beta$-ketoasilACP KasA sintase. Tiolaktomisin berinteraksi dengan asam amino histidin311A, sistein171A, dan histidin345A pada kantong aktif enzim ${ }^{17}$. Enzim asam mikolat siklopropana sintase memiliki ligan utama senyawa N-oktil oktan-1-amin yang berinteraksi dengan asam amino glisin145A ${ }^{15}$.

Optimasi dilakukan menggunakan aplikasi VegaZZ seperti yang disajikan pada Gambar 4 dan 5. Optimasi geometri sangat diperlukan dalam proses penambatan molekul, senyawa uji dioptimasi geometri agar diperoleh struktur yang stabil. Struktur yang stabil didapatkan dengan menghitung nilai tolakan dari setiap gugus yang memberikan andil yang penting dalam proses interaksi dengan asam amino pada protein target. Parameter nilai tolakan dari setiap gugus fungsi dihitung menggunakan perhitungan mekanik dan pola Gaussian.

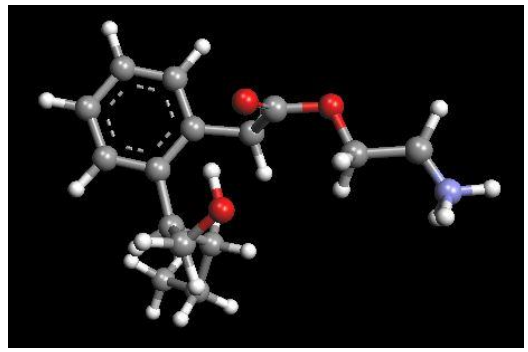

Gambar 4. Gambar Tiga Dimensi dari Proses Optimasi Senyawa 2iminoethyl 2-(2-(1-hydroxypentan-2-yl) phenyl)acetate

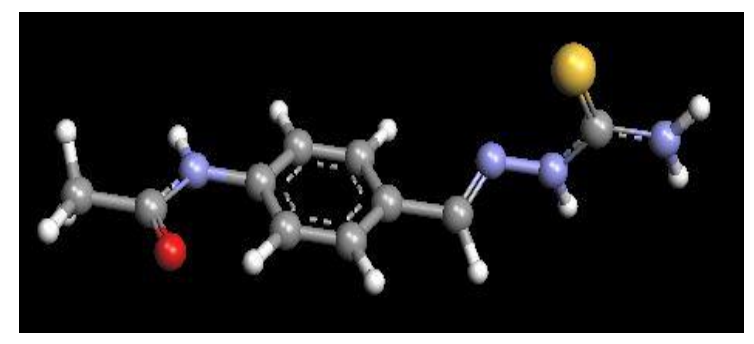

Gambar 5. Gambar Tiga Dimensi dari Proses Optimasi Thiocetazone

Validasi metode penambatan molekul dilakukan dengan membandingkan antara posisi ligand asli N-oktil oktan-1-amin (3HEM) dan tiolaktomisin (2WGE) terhadap reseptor yang telah diuji secara eksperimental dengan posisi ligan yang sama (ligand copy). Iterasi yang digunakan pada validasi protein kode 3HEM adalah sumbu x(21113000), 
y(19983000), dan z(20998000) sedangkan pada validasi protein kode 2WGE adalah sumbu $\mathrm{x}(18162000)$, $\mathrm{y}(18000000)$, dan $\mathrm{z}(17001111)$. Resolusi grid pada $0,4 \AA$ dengan kondisi ligan fleksibel. Kondisi ligan fleksibel menunjukkan ligan memungkinkan untuk melakukan penyesuaian struktur dalam mencapai struktur yang stabil saat berikatan dengan reseptor (Gambar 6).

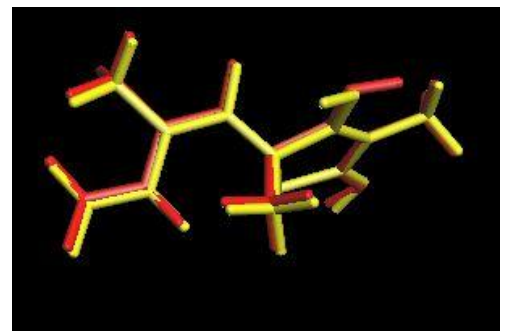

Gambar 6. Hasil Validasi yaitu Tumpang-Tindih Pose Senyawa Referensi yang Diperoleh dari Struktur Kristal Protein Enzim $\beta$-ketoasilACP KasA sintase (atom karbon berwarna merah) dan Pose Senyawa Hasil Docking (atom karbon berwarna kuning)

RMSD (Root Mean Square Deviation) merupakan dasar yang digunakan untuk memberikan penilaian pada validitas metode. Metode yang digunakan dikatakan valid jika nilai RMSD yang diperoleh $\leq 2,5^{16}$. Berdasarkan hasil validasi ligan asli N-oktil oktan-1-amin (3HEM) dan tiolaktomisin (2WGE) terhadap ligand copy, diperoleh nilai RMSD sebesar 2,4638 pada protein kode 3HEM dan 0,1608 pada protein kode 2 WGE pada kondisi ligan fleksibel.

Hasil validasi didapatkan hasil yang valid, hasil tersebut menunjukkan bahwa protokol tersebut dapat digunakan untuk penapisan secara virtual dalam upaya penambatan molekul senyawa 2-iminoethyl 2-(2-(1hydroxypentan-2-yl) phenyl)acetate pada protein target (Gambar 7). Target penambatan molekul senyawa 2iminoethyl 2-(2-(1-hydroxypentan-2-yl) phenyl)acetate diasumsikan sama dengan sisi ikatan kedua enzim dengan masing-masing ligan (N-oktil oktan-1-amin (3HEM) dan tiolaktomisin (2WGE)) karena senyawa tersebut memiliki kemiripan gugus dengan Thiacetazone. Semakin kecil nilai RMSD maka semakin baik metode yang dilakukan dan parameter penambatan molekul yang digunakan adalah dalam keadaan ligan fleksibel.

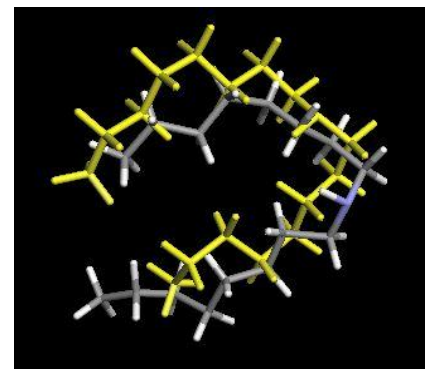

Gambar 7. Hasil Validasi yaitu Tumpang-Tindih Pose Senyawa Referensi yang Diperoleh dari Struktur Kristal Protein Enzim Asam Mikolat Siklopropana Sintase (atom karbon berwarna abu-abu) dan Pose Senyawa Hasil Docking (atom karbon berwarna kuning)

\section{Diskusi}

Residu asam amino histidin311A, sistein171 A, dan histidin345A yang merupakan residu asam amino dari active site enzim $\beta$-ketoasil-ACP KasA sintase pada protein dengan kode $2 \mathrm{WGE}^{14}$ dan residu asam amino glisin145A pada active site enzim asam mikolat siklopropana sintase dengan kode $3 \mathrm{HEM}^{17}$.Parameter yang diamati adalah energi bebas Gibbs $(-\Delta \mathrm{G}$ (kkal/mol) hasil interaksi reseptorligan,jarak dan residu asam amino yang terdekat dengan ligand $(<5$ Á). Hasil docking yang dilakukan pada protein target disajikan pada Tabel 1, Tabel 2, Tabel 3, dan Tabel 4.

Tabel 1. Hasil Docking Pada Protein Enzim $\beta$-ketoasil-ACP KasA sintase

\begin{tabular}{lc}
\hline \multicolumn{1}{c}{ Senyawa } & $\begin{array}{c}\text { Energi Ikatan Reseptor-Ligand } \\
(-\Delta \mathrm{G})(\mathrm{kkal} / \mathbf{m o l})\end{array}$ \\
\hline Tiolaktomisin (native ligand) & $-8,8920$ \\
\hline Thiacetazone & $-5,5030$ \\
\hline $\begin{array}{l}\text { 2-iminoethyl 2-(2-(1- } \\
\text { hydroxypentan-2-yl) } \\
\text { phenyl)acetate }\end{array}$ & $-10,7934$ \\
\hline
\end{tabular}

Hasil perhitungan menunjukkan bahwa senyawa 2iminoethyl 2-(2-(1-hydroxypentan-2-yl) phenyl)acetate mempunyai skor ikatan yang lebih besar daripada senyawa tiolaktomisin dan thiacetazone (Tabel 1). Senyawa 2iminoethyl 2-(2-(1-hydroxypentan-2-yl) phenyl)acetate berinteraksi dengan residu asam amino histidin311 dan sistein 171 pada site active enzim $\beta$-ketoasil-ACP KasA sintase (Gambar 10). Skor $-\Delta \mathrm{G}$ senyawa 2-iminoethyl 2-(2(1-hydroxypentan-2-yl) phenyl)acetate lebih kecil dibandingkan dengan skor $-\Delta \mathrm{G}$ tiolaktomisin yang telah diketahui mempunyai aktivitas sebagai penghambat enzim $\beta$-ketoasil-ACP KasA sintase. Oleh karena itu, senyawa 2iminoethyl 2-(2-(1-hydroxypentan-2-yl) phenyl)acetate secara in silico dapat dikatakan ikatannya dengan sisi aktif lebih kuat dan reaksi dapat lebih mudah terjadi pada protein enzim $\beta$-ketoasil-ACP KasA sintase sehingga layak untuk diteliti lebih lanjut aktivitasnya.

Tabel 2. Ikatan Hidrogen Senyawa dengan Asam Amino Enzim $\beta$ ketoasil-ACP KasA sintase

\begin{tabular}{lcccc}
\hline \multicolumn{1}{c}{ Senyawa Uji } & $\begin{array}{c}\text { Jumlah } \\
\text { Ikatan } \\
\text { Hidrogen }\end{array}$ & $\begin{array}{c}\text { Jarak } \\
\text { Ikatan } \\
\left(\begin{array}{l}\text { Á) } \\
\text { Tiolaktomisin }\end{array}\right.\end{array}$ & $\begin{array}{c}\text { Asam Amino } \\
\text { Yang } \\
\text { Berikatan }\end{array}$ & $\begin{array}{c}\text { Gugus } \\
\text { Senyawa } \\
\text { Yang } \\
\text { Berikatan }\end{array}$ \\
\hline (native ligand) & 3 & 2,9087 & Histidin311 & H-O \\
& & 2,9876 & Sistein171 & H-O \\
\hline Thiacetazone & 1 & 2,24477 & Histidin345 & H-O \\
& & & & Glisin403 \\
& & & & \\
\hline 2-iminoethyl 2- & 5 & 2,9669 & Glisin318 & H-O \\
(2-(1- & & 2,1698 & Threonin315 & H-O \\
hydroxypentan- & & 2,9996 & Sistein171 & H-O \\
2-yl) & & 2,2986 & Histidin311 & H-O \\
phenyl)acetate & & 2,8268 & Fenilalanin402 & N-O \\
& & & &
\end{tabular}


Dari Tabel 3 diketahui bahwa senyawa 2iminoethyl 2-(2-(1-hydroxypentan-2-yl) phenyl)acetate mampu berikatan dengan lebih baik terhadap enzim asam mikolat siklopropana sintase, hal itu dibuktikan dari energi ikatan bebas Gibbs $(\Delta \mathrm{G})$ senyawa 2-iminoethyl 2-(2-(1hydroxypentan-2-yl) phenyl)acetate lebih kecil daripada thiocetazone dan asil N-oktil oktan-1-amin (native ligand). Senyawa 2-iminoethyl 2-(2-(1-hydroxypentan-2-yl) phenyl)acetate mampu berinteraksi dengan residu asam amino glisin 145 pada site active dari enzim asam mikolat siklopropana sintase dan mampu berikatan dengan residu asam amino sekunder yaitu tirosin41. Jumlah ikatan hidrogen senyawa 2-iminoethyl 2-(2-(1-hydroxypentan-2yl) phenyl)acetate terhadap asam amino pada sisi aktif enzim asam mikolat siklopropana sintase relatif lebih banyak jumlahnya daripada ikatan antara ligan asli dan thiacetazone dengan enzim (Tabel 4). Jumlah ikatan hidrogen yang lebih banyak akan mendukung kekuatan ikatan yang lebih besar antara senyawa dengan sisi aktif enzim. Oleh sebab itu, dapat disimpulkan bahwa senyawa 2 iminoethyl 2-(2-(1-hydroxypentan-2-yl) phenyl)acetate secara hipotesis dapat dikatakan ikatannya dengan sisi aktif lebih kuat dan reaksi dapat lebih mudah terjadi pada enzim asam mikolat siklopropana sintase yang lebih baik daripada asil N-oktil oktan-1-amin (native ligand) dan thiacetazone secara in silico (Gambar 8).

Tabel 3. Hasil Docking Pada Enzim Asam Mikolat Siklopropana Sintase

\begin{tabular}{lc}
\hline \multicolumn{1}{c}{ Senyawa } & $\begin{array}{c}\text { Energi Ikatan Reseptor-Ligand } \\
(-\Delta \mathbf{G})(\mathbf{k k a l} / \mathbf{m o l})\end{array}$ \\
\hline $\begin{array}{l}\text { Asil N-oktil oktan-1-amin } \\
\text { (native ligand) }\end{array}$ & $-4,0986$ \\
\hline Thiacetazone & $-7,1675$ \\
\hline $\begin{array}{l}\text { 2-iminoethyl 2-(2-(1- } \\
\text { hydroxypentan-2-yl) } \\
\text { phenyl)acetate }\end{array}$ & $-11,9791$ \\
\hline
\end{tabular}

Tabel 4. Ikatan Hidrogen Senyawa dengan Enzim Asam Mikolat Siklopropana Sintase

\begin{tabular}{|c|c|c|c|c|}
\hline Senyawa Uji & $\begin{array}{c}\text { Jumlah } \\
\text { Ikatan } \\
\text { Hidrogen }\end{array}$ & $\begin{array}{c}\text { Jarak } \\
\text { Ikatan } \\
\text { (Á) }\end{array}$ & $\begin{array}{c}\text { Asam } \\
\text { Amino } \\
\text { Yang } \\
\text { Berikatan }\end{array}$ & $\begin{array}{c}\text { Gugus } \\
\text { Senyawa } \\
\text { Yang } \\
\text { Berikatan }\end{array}$ \\
\hline $\begin{array}{l}\text { Asil N-oktil } \\
\text { oktan-1- } \\
\text { amin (native } \\
\text { ligand) }\end{array}$ & 1 & 2,0967 & Glisin145 & $\mathrm{H}-\mathrm{O}$ \\
\hline Thiacetazone & 2 & $\begin{array}{l}2,9345 \\
2,9927\end{array}$ & $\begin{array}{l}\text { Tirosin41 } \\
\text { Glisin145 }\end{array}$ & $\begin{array}{l}\mathrm{N}-\mathrm{O} \\
\mathrm{H}-\mathrm{O}\end{array}$ \\
\hline $\begin{array}{l}\text { 2-iminoethyl } \\
2-(2-(1- \\
\text { hydroxypenta } \\
\text { n-2- } \\
\text { yl)phenyl)ace } \\
\text { tate }\end{array}$ & 3 & $\begin{array}{l}2,9002 \\
2,8976 \\
2,8789\end{array}$ & $\begin{array}{l}\text { Glisin145 } \\
\text { Tirosin41 } \\
\text { Tirosin41 }\end{array}$ & $\begin{array}{l}\mathrm{H}-\mathrm{O} \\
\mathrm{N}-\mathrm{O} \\
\mathrm{H}-\mathrm{O}\end{array}$ \\
\hline
\end{tabular}

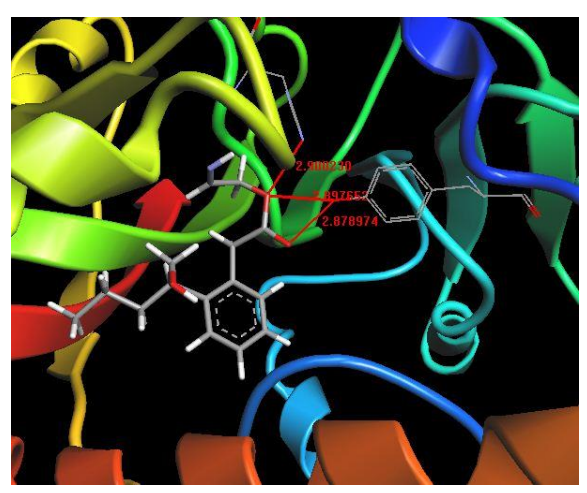

Gambar 8. Visualisasi Interaksi Senyawa 2-iminoethyl 2-(2-(1hydroxypentan-2-yl) phenyl)acetate dengan Enzim Asam Mikolat Siklopropana Sintase

Penelitian ini masih memiliki keterbatasan diantaranya perlu adanya analisis molecular dynamic yang bertujuan untuk mengukur kemampuan interaksi antara ligand dan asam amino secara spesifik. Diharapkan untuk ke depannya dapat dilakukan penelitian lebih lanjut secara invitro pada enzim $\beta$-ketoasil-ACP KasA sintase dan enzim asam mikolat siklopropana sintase untuk membuktikan bahwa pendekatan penambatan molekul tersebut berkorelasi positif.

\section{Daftar Pustaka}

1. Sebastianes, F.L.S., Cabedo, N., El Aouad, N., Valente, A.M.M.P., Lacava, P.T., Azevedo, J.L,. 3hydroxypropionic acid as an antibacterial agent from endophytic fungi Diaporthe phaseolorum. Current microbiology. 2012. 65: 622-632.

2. WHO.France: World Health Organization. 2012. P.iv 3, 11, 20, 71 .

3. Houben, R.M.G.J. and Dodd, P.J. The global burden of latent tuberculosis infection: a re-estimation using mathematical modelling. PLoS Med. 2016. 13, e1002152.

4. Ren, C.L., Konstan, M.W., Yegin, A., Rasouliyan, L., Trzaskoma, B., Morgan, W.J.,. Multiple antibioticresistant Pseudomonas aeruginosa and lung function decline in patients with cystic fibrosis. Journal of Cystic Fibrosis. 2012.11: 293-299.

5. Iwamoto, M., Mu, Y., Lynfield, R., Bulens, S.N., Nadle, J., Aragon, D,. Trends in invasive methicillinresistant Staphylococcus aureus infections. Pediatrics. 2013. 132: e817-824.

6. Tanaka, M., Sukiman, H., Saito, M., Suto, K., Prana, M., dan Tomita, F., Isolation, Screening and Phylogene-tic Identification of Endophytes from Plants in Hokaido Japan and Java Indonesia. Microbes and Environment.1999.14: 237-241.

7. Tan, R.X. dan Zou, W.X.,. Endophytes: a rich source of functional metabolites. Natural product reports, 2001.18: 448-459. 
8. Strobel, G.A.,. Endophytes as sources of bioactive products. Microbes and infection / Institut Pasteur. 2003. 5: 535-544.

9. Rollando,R.,Aditya,M.,,Notario,D.,Monica,E.,Sitepu, R.,. Penelusuran aktivitas antibakteri, antioksidan, dan sitotoksik fungi endofit genus fusarium sp. diisolasi dari daun meniran (Phyllantus niruri Linn.), Pharmaciana. 2017 :95-104.

10. Rollando,R.,Notario,D.,Monica,E., Aditya,M .,Sitepu,R.. Antimicrobial, antioxidant, and cytotoxic activities of endhopitic fungi Chaetomium sp. isolated from Phyllanthus niruri Linn: in vitro and in silico studies, The journal of pure and applied chemistry research. 2017.6 : 64-83.

11. Chintu, C., Luo, C., Bhat, G., Raviglione, M., DuPont, H., dan Zumla, A.,. Cutaneous hypersensitivity reactions due to thiacetazone in the treatment of tuberculosis in Zambian children infected with HIV-I. Archives of Disease in Childhood. 1993.68: 665-668.

12. Alahari, A., Trivelli, X., Guérardel, Y., Dover, L.G., Besra, G.S., Sacchettini, J.C.,. Thiacetazone, an antitubercular drug that inhibits cyclopropanation of cell wall mycolic acids in mycobacteria. PloS One. 2007.2: e1343.

13. Grzegorzewicz, A.E., Korduláková, J., Jones, V., Born, S.E.M., Belardinelli, J.M., Vaquié, A.,. A common mechanism of inhibition of the Mycobacterium tuberculosis mycolic acid biosynthetic pathway by isoxyl and thiacetazone. The Journal of Biological Chemistry. 2012. 287: 38434-38441.

14. Luckner, S.R., Machutta, C.A., Tonge, P.J., dan Kisker, C.. Crystal Structures of Mycobacterium Tuberculosis KasA Show Mode of Action within Cell Wall Biosynthesis and its Inhibition by Thiolactomycin. Structure. 2009.17: 1004.

15. Barkan, D., Liu, Z., Sacchettini, J.C., dan Glickman, M.S.Structure of Mycobacterium tuberculosis Mycolic Acid Cyclopropane Synthase CmaA2 in Complex with Dioctylamine.The Journal of Biological Chemistry. 2009. 287: 34-38441.

16. Istyastono, E.., Yuniarti, N., dan Jumina. Sintesis Senyawa Berpotensi sebagai Inhibitor Angiogenesis : 2-benzilidenasikloheksana-1,3-dion. Majalah Farmasi Indonesia. 2009.(1-8).

17. Barkan, D., Liu, Z., Sacchettini, J.C., Glickman, M.S. Structure of Mycobacterium tuberculosis Mycolic Acid Cyclopropane Synthase CmaA2 in Complex with Dioctylamine. Structure. 2009. 16: 1018. 